\title{
The Identity Construction of Young Gay on Instagram
}

\author{
Fatmawati Moekahar ${ }^{1}$, Asrinda Amalia ${ }^{2}$ \\ ${ }^{1}$ ORCID iD: 0000-0001-7011-1652, Universitas Islam Riau, J1. Kaharuddin Nasution \\ 113 Pekanbaru, Riau 28284, Indonesia \\ ${ }^{2}$ ORCID iD: 0000-0002-5732-5725, Universitas Muhammadiyah Riau, J1. KH. Ahmad \\ Dahlan 88, Pekanbaru, Riau 28156, Indonesia \\ *Corresponding author, e-mail: fatmawatikaffa@comm.uir.ac.id
}

\begin{abstract}
In Indonesia in the last five years, homosexuals still experience discrimination. This condition causes the gay to create new identities that are constructed. Instagram is a medium that is currently widely used by gay in social interactions. This media is used by gays to construct their identity. This study aims to find out how they construct their identity through instragram social media, and what their identity is different in the real world and cyberspace in Bandung. This research method is qualitative with a phenomenological study approach. The informants in this study were gay groups in Bandung City, expecially gay young. Sampling technique used to purposive sampling with deep interview, observation and documentation. The results of this study say that one's experience of being gay is driven by internal environmental factors, namely the treatment of discrimination from family members, colleague and friends. The popular features of Instagram used by informants on Instagram are posting photo, video, and comment by share story to post. Gays construct their identity through online and offline media. Researchers found that there were two stages (front stage and back stage) played by gays when interacting with others.

Keywords: Identity Construction, Gay, Phenomenology, Instagram.
\end{abstract}

\section{Introduction}

The most popular social media among teenagers is Instagram, and young gays are no exception. According to NapoleonCat.com, by the end of 2020 Instagram users in Indonesia have increased, especially among teenagers (aged 18-24 years), namely $36.1 \%$ of the 69 million Instagram users (Napoleoncat.com, 2020). Instagram has become the most popular medium to show their identity as gay people. This is of course a phenomenon that deserves to be a reference for researchers who are interested in conducting research which focuses on gay life on social media and how it has an effect. We can see this from several studies on the use of social media for gay people in Indonesia, including: social construction through intrapersonal communication of gay students in Bandung (Diniati, 2018); The dynamics of gay identity in the public space of Toboali, South Bangka (Rahmawan \& Sujadmi, 2021). This research focuses on the experience of young gays in constructing their identity through Instagram media and gay self-construction through intrapersonal communication in society.

Based on the results of these previous studies, we find the fact that it turns out that young gay people on their Instagram social media do not need to pretend to be heterosexual, both in Indonesia and in some worlds. Examples of these young gay communities include: @komunitasgayindonesia (the number of followers is 3064); @ gay_community (1715 followers); @1.g.b.t.group (20.9K followers). 


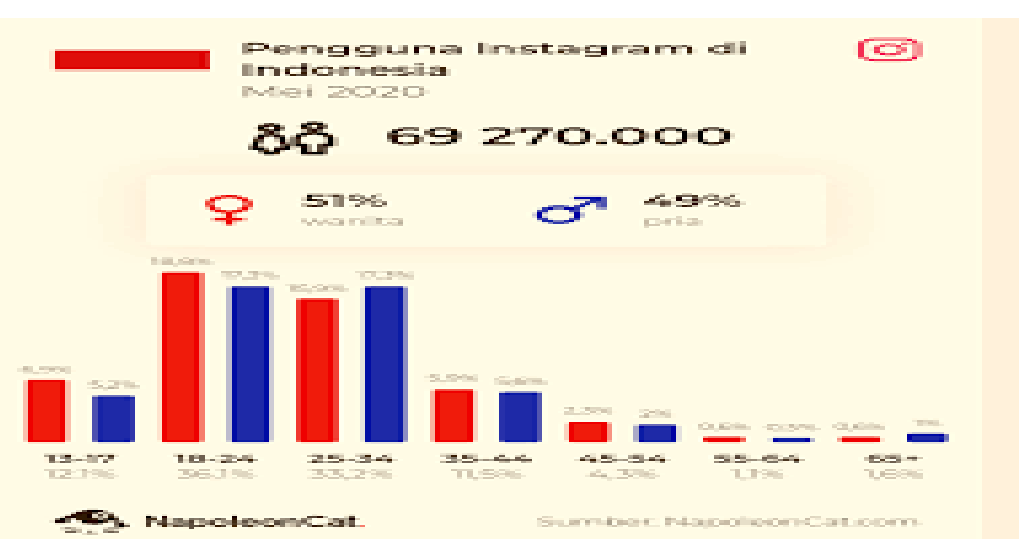

Figure 1. Instagram Users in Indonesia

(source: tekno.kompas.com/image/2019/12/23/14020057/sebanyak-inikah-jumlahpengguna-instagram-di-indonesia)

Indonesia has no national law that prohibits homosexuality, except for UndangUndang No. 1/1974 concerning marriage. This law stipulates that legal marriages are only marriages between heterosexual couples, but wider discrimination occurs in the LGBT (Lesbian, Gay, Bisexual, and Transgender) community. In the last five years, discrimination against gender and sexual minorities in Indonesia has increased. Nongovernmental organizations that focus on advocacy for LGBT rights have recorded various acts of discrimination, ranging from bullying to murder. The media in Indonesia has an important role in creating stigma against the LGBT community. Anti-Gay media prejudice can be seen from the news headlines, news point of view, word choice, and the selection of their sources. This marginalization and stigma causes the gay community in Indonesia to avoid appearing in public spaces and media (Azhari et al., 2019). It was found that the gay community in Indonesia used social media to change stigma. Until now, Indonesian people continue to label homosexuality as deviant sexual behavior. Through social media, the gay community tries to fight this labeling by avoiding extreme expressions of sexuality. Through social media, the gay community denounced actions that exacerbated the stigma against them.

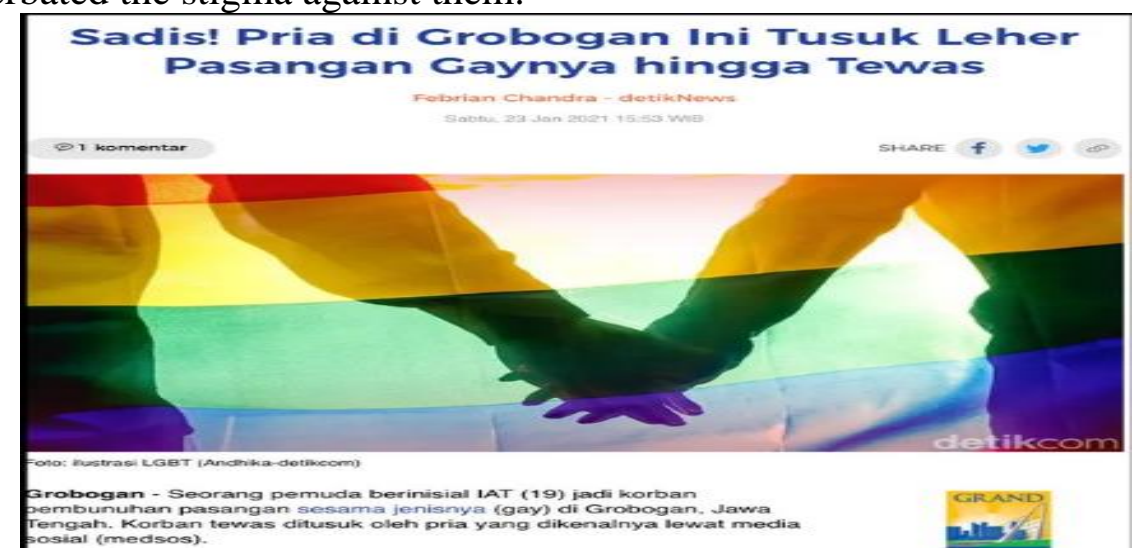

Figure 2. Gay News in the Media

(source: news.detik.com/berita-jawa-tengah/d-5345749/sadis-pria-di-grobogan-initusuk-leher-pasangan-gaynya-hingga-tewas)

Figure 2 describes the acts of violence committed by gays to the occurrence of murder. This news gives a perception to the public so that it creates a negative stigma against gay people. The development of social media nowadays has progressed very rapidly. One of the most popular social media is Instagram. Instagram is able to attract 
users from all walks of life, from different backgrounds and ages. Instagram has become an integral part of the communication and lifestyle of people in various parts of the world. A person can show his identity through photos, videos, opinions and other things that are part of his identity with Instagram. Identity becomes an important dimension inherent in human relations because a person's existence is always part of an ethnic group, religion, tradition and language of a certain cultural system. Social media is a means that can accommodate someone's interests to be able to communicate their identity to others. The identity on social media are easier to form and modify (Lailiyah, 2015).

Identity in the real world can be encountered through various things, including: clothing, race, religion, sex, status, and others. (Khazraee \& Novak, 2018) has found that social media (Facebook) is able to form a collective identity. Social media has a growing importance in the construction of professional identities society (Kasperiuniene, 2019); Jaspal (2015) explained social representations, identity, and social relations among nonheterosexual British Asian men. But through social media on the internet, one can hide certain identities, such as sex, religion, status etcetera. Appearance in social media can be manipulated with various look as desired, even away from its original form. Someone who in the real world of male sex, tall and brown skin can be constructed through the media Instagram with the appearance of women, slim and white. Even those who have married and have children can still claim to be single.

This is what said, that the operationalization of identity in the virtual world becomes identity fluedity, renovated hierarchies, and information as reality (Jordan, 2000). The identity of fluedity means a process of establishing an identity online or virtual and this formed identity is not necessarily identical or close to its identity in the real world (offline identities). Renovated hierarchies are the processes by which the hierarchies that take place in the world of his or her mind are re-shaped into online hierarchies. The end result of the identity of fluedity and renovated hierarchies is then the informational space, ie information that describes the reality that only applies in the virtual world. Associated with this phenomenon, (Berger \& Luckmann, 2011) also says that individuals are in fact doing the construction of themselves by way of self-presenting. But the appearance of the self is basically formed or to meet the desires of the audience or social environment, not derived from the self and not also created by the individual itself. So the identity that emerges is the depiction of what is actually a desire and to meet the needs of social recognition and human identity can vary depending on the interaction with others. Individuals who use cyberspace to build their identities are individuals whose real identity is not acceptable in the real world.

The LGBT people are examples of the group experiencing the condition. In Indonesia, this group became one of the community groups that continue to get multidimensional discrimination. Discrimination here in may be interpreted as an unjust service or treatment of a particular individual, whereby the different treatment is based on the characteristics represented by the individual, such as ethnicity, religion, sex, political choice, sexual orientation etc. which ignores the legitimate or reasonable objectives. Research about discrimination of LGBT there are discrimination to the young bisexual women (Mcclelland \& Rubin, 2016); adaptation to sexual orientation stigma (Balsam \& Mohr, 2007); discrimination in employment, housing, and public accommodations in Texas (Mallory et al., 2017); ignoring bisexuality (Alarie \& Gaudet, 2013); discrimination of young bisexual woman (Mcclelland \& Rubin, 2016).

This paper specifically discusses the construction of young gay identity on Instagram. Some gays do not necessarily explore their identity according to the real world. 
They hide their identity with various manipulations that can be used through the formation of a new identity on social media Instagram. There are striking differences between online and offline identities (Owens, 2016); pseudonimity in social media is to avoid the stereotype threats (Triputra \& Rewindinar, 2020). Someone will form a new identity that they want to show when they are online on social media. But on the other hand, gays have also dared to come out through online media (various social media, including Instagram) to communicate their real identity. They consider that social media is a media that can accept the full presence of these people. (Fox \& Ralston, 2016) revealed that the choice of gays to use social media is because they can choose an identity to be themselves or others while exploring, controlling the flow of information, or experimenting with selfexpression so that their identity develops and is integrated with the online world from time to time.

The gay group is one of the groups that uses social media as a means of forming self-identity. This is due to the assumption that this gay group lacks acceptance in the real world. Against this background, homosexuals try to close themselves and even hide their identity in public. The individual's ability to manage his behavior and everything in himself to convey a self-image that Goffman wants to show is called the concept of impression management. This concept is included in the dramaturgy theory. This theory says that social interaction is interpreted the same as a drama show. Humans are actors who seek to combine personal characteristics and goals with others through their own drama performances. In achieving that goal, man will develop the behaviors that support his role. This study will discuss how gay especially homosexuals who construct their identity through social media Instagram as a result of social discrimination against them. Many people do not know the reason why they chose different sexual orientations. The existence of homosexuals in Indonesia has already a negative label, that their circles are grouped as part of abnormal society. So often they try to cover up their original identity by admitting frankly in the daily association. Even some of them do bicultural identity, ie two identities possessed by a gay man who does not change his sexual orientation by staying gay but has children and wife.

\section{Methods}

The research method used is qualitative research with phenomenology approach. The qualitative research is a research that aims to understand phenomena about what the research subject went through in terms of behaviors, perceptions, motivations, or holistic actions described by words and language (Moleong, 2017). This phenomenological research aims to identify and describe the subjective experience of young gays in the construction of identity through Instagram social media. By trying to explain or reveal the meaning of the concept or the phenomenon of experience based on awareness that occurs in some gays. This research is conducted in a natural situation, so that there is no limit in interpreting or understanding the phenomena studied. The phenomenological approach delayed all judgments about natural attitudes until found a certain basis. This delay is called epoche (time period). The epoche concept is central to where researchers construct and classify early guesses about phenomena to understand what the informant says. Selection of informants was done by purposive technique. There are five young gay's informant in Bandung city with purposive sampling. Informants are young gay who often get discriminated against in their daily lives, both in their family, friends, playmates at home and even in their work environment. In this research, researcher uses primary and secondary data. The Primary data from key informants by in depth interview 
and observation, while secondary data were obtained from documentation of informant's Instagram post.

\section{Results}

Gay using Instagram

The results of this study are presented based on the results of the exploration of the experiences of the five young gay informants in constructing themselves through Instagram. In order to maintain the privacy of the five informants, the researchers did not use their real names but their initials, because they also object if their names are published. In general, the researchers did not find any problems in accessing informants.

Instagram is one of the most popular social media in the world, especially for teenagers. Instagram is a photo sharing application that allows users to take photos, apply digital filters, and share them on various social networking services. This visual basis causes social media to be favored by teenagers, especially those who have a hobby of being through photos and videos. Social media has become part of the adult experience for teenagers (Spies \& Gayla, 2014). Many Instagram users aim to express their respective personalities through Instagram social media, one of which is to fulfill their pleasure and satisfaction through uploading the photos they do. This was also done by gay groups who were informants in this study. The following is the use of Instagram by informants: 'selfexpression.' The five informants acknowledged that Instagram is a medium for expression. Through this media, informants can express themselves through photos and videos uploaded to their accounts.
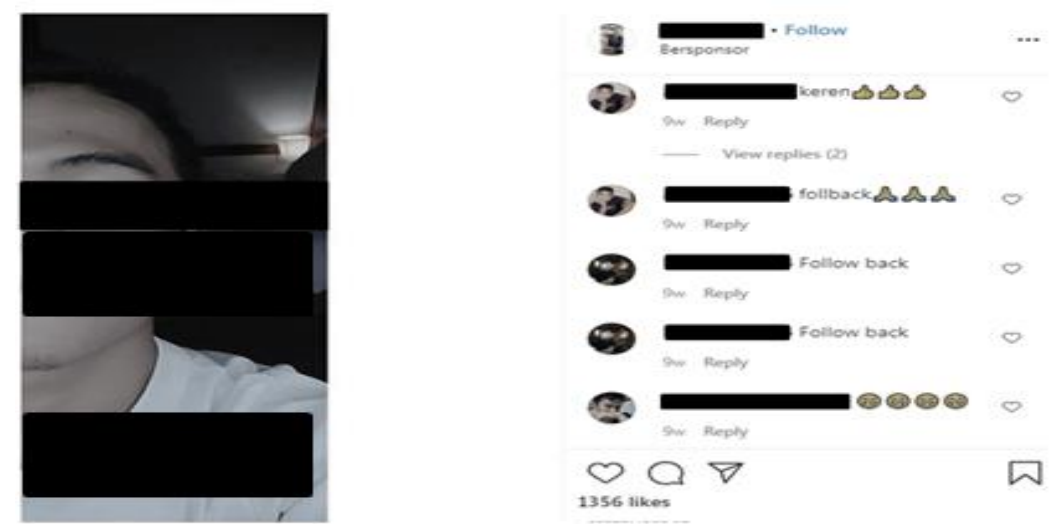

Figure 3. Informant's expression on Instagram

(source: screen capture of the informant on his Instagram account, initial AN)

Many Instagram users aim to express their respective personalities through Instagram social media, one of which is to fulfill their pleasure and satisfaction through uploading the photos they do. In terms of uploading photos on Instagram, it can provide freedom of expression to fulfill its own satisfaction. 'Searching for information': informants admit that being part of the adolescent age group, of course, they need a lot of information about everything related to education, career, friendship and what information is currently up to date. The three informants (DD, AN and TN) admitted that Instagram was able to provide the latest information they needed. Meanwhile, SN and $\mathrm{AB}$ were lacking in exploring Instagram for information search. 'Follow trends': the informant admitted that he followed the trend that was viral in various fields through Instagram. Trends can be fashion, sports, food, hangouts, news, online shops, etcetera. 'Add friends/followers': the informants admitted that they got many friends from 
Instagram. These friends can come from various regions in Indonesia and even from abroad (informant DD).

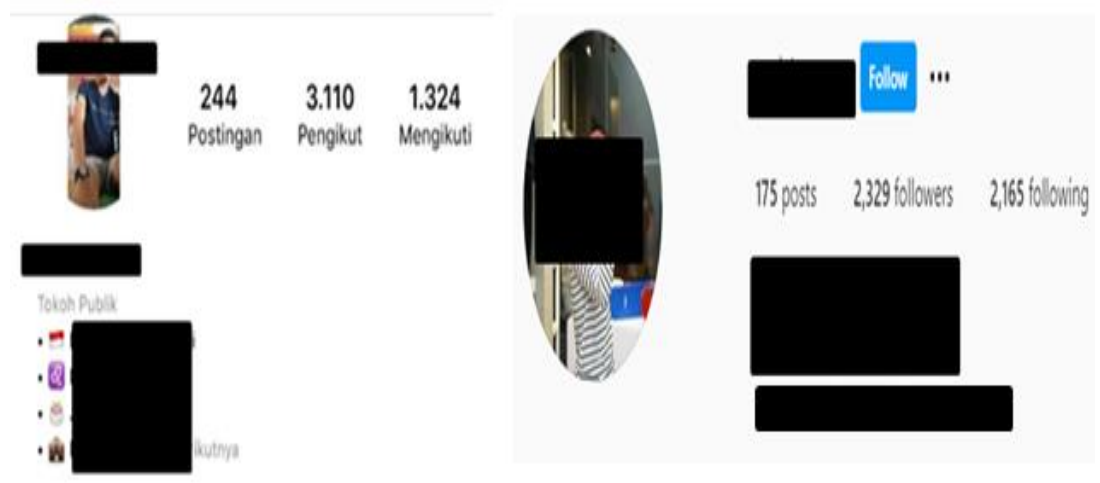

Figure 4. Number of Followers on Instagram

(source: screen capture of the informant on their Instagram account, initials DD and TN)

Teens around the world are so attached to social media, they continue to communicate via social media, even while eating, walking and studying. Time spent on social media is often more than time spent studying or hanging out with family. Various things are the reasons social media is so attractive to teenagers, some of the reasons are getting attention, asking for opinions, growing an image, hobbies and making friends. In exploring social media Instagram, some of the features most frequently used by informants are as follows: a) 'Share story to post', the informant admitted that he most often shares photos/videos on the story menu, then shares in the post menu. The purpose of the informant to do this is so that all friends and followers are aware of the up date activities they are doing. Other than that this feature brings traffic from Instagram Stories to Feeds or to other people's content. b) 'Tag and Hashtag', used to tag friends and expand the reach or reach of content, in addition to collecting photos that have the same thing. c) 'DM (direct message)', which is a prayer feature that allows Instagram users to send and receive messages directly. This feature is also an important part of informants' use, especially if it covers something private.

The Construction of Gay Identity in Instagram

The presence of social media such as Instagram into a medium that can meet the individual needs of communication and can encourage more freely each individual to reveal who they are. Instagram is a perfect medium of how a technology that can encourage and provide space for each individual in their self-constructing, especially for gays. In terms of reality, the use of social media such as Instagram, they use to construct the original identity in order not to be known by the public. This is revealed by the five research informants. DD and AN reveal through Instagram can more freely express the original form without having to pretend. They feel that Instagram is a medium that 'understands' their real condition. Even through Instagram both of these informants finally found a lover. They communicate continuously though only through Instagram media because in fact they are also aware when in the real world (offline) it is not possible for them to meet. 


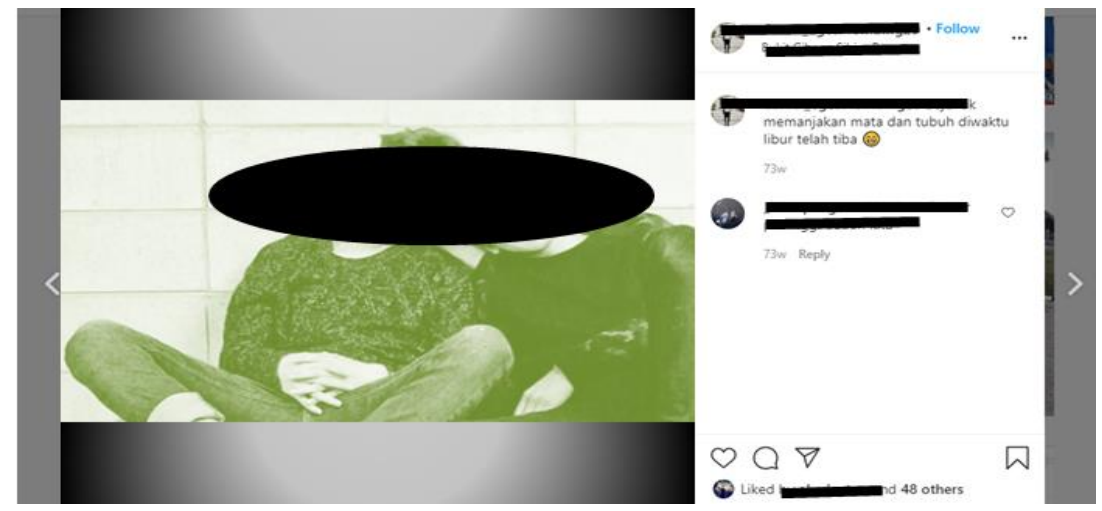

Figure 5. Close Relationship in Instagram

(source: screen capture of the informant on his Instagram account, initial DD)

Unlike the other three informants, $\mathrm{SN}, \mathrm{AB}$ and $\mathrm{TN}$ are 'hidden gay'. Instagram media is used as a means to create and improve its true identity as gay. This is done because the number of friends in the media are their friends in everyday life. Therefore they act the same as what he does in his association. They cover the gay identity, act 'normal' as a man, and even have a girlfriend who has become her lover in the real world. With Instagram media will facilitate informants in constructing identity in the real world (offline identity), play the role well and more assertive and convincing to everyone that what they play is the real condition.

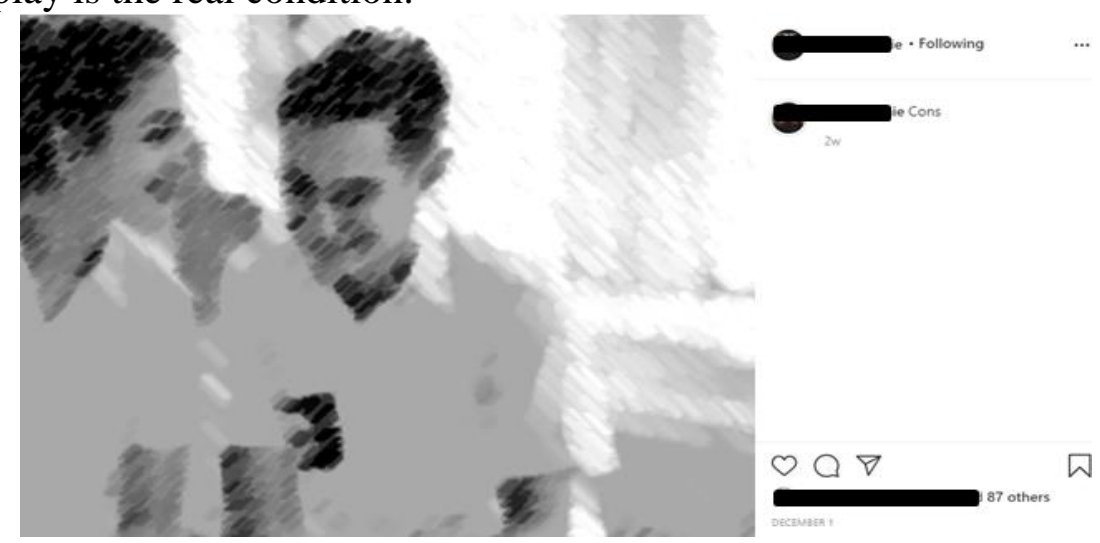

Figure 6. Informant with his Girlfriend

(source: screen capture of the informant on his Instagram account, initial AB)

Factors of discrimination and large rejection in Indonesia against the LGBT this is causing the five informants of this study to construct identity in the life bermediaya. By communicating through Instagram (online identity), informants find it easier to do their activities without having to be afraid and ashamed as they encountered in real life. In Indonesia, gay groups still have not gained recognition to this day. Society still considers that their existence is part of social deviation. Therefore, they often get discriminatory treatment. Even their negative treatment and outlook are also directed to their other (nongay) family members. Gay informers will inevitably encounter conflicts over their gay identity with the feelings of their parents, other family members if until their identity is known as one of the minority members of Indonesian society.

In constructing identity in Instagram, the five informants of this research are divided into two groups, namely hidden gay and open gay. The hidden gay groups are $\mathrm{SN}, \mathrm{AB}$ and TN. This informant uses their real name and photo as in real life. They are friends and associate with the same people, even Instagram is used to give more false confessions as gay people. Covering his original condition as a gay man. They act as normal men who 
are very different from reality. While DD and AN become a real person when in social media Instagram. They display fake names and photos that are not their real identities. According to these two informants, precisely by giving a false identity like this, they can act as a whole and perfect human without having to pretend as a normal male figure.

Despite having different ways of constructing their identities, these two groups of informants have the same goal of hiding their sexual orientation. Informants do things that are not done in the offline identity to support the success of online identity. If in real life, DD and AN are quiet figures, different when in social media they become personal and communicative. When together with her lover in cyberspace, these two informants are very careful. Unlike the other three informants, they have an attitude that is 'closed' when in cyberspace. Even with their lovers their communication is limited, because they cover the original form as a gay. Both of these gay groups use social media Instagram as a medium to construct identity to reinforce and reassure what they do in the offline world. The Construction of Offline (Real Life) on Gay Identity

In ancient times heterosexual phenomena were hard to find, but now they are slowly beginning to open themselves from the public. The emergence of such phenomena make some people interested to discuss and find out where and how the phenomenon came. But in Indonesia alone, this phenomenon is still considered quite taboo and is part of a minority group so that this group is very closed and does not recognize his identity.

Discriminatory treatment that they often feel and accept in various aspects of life makes them act shut down. The expression of cynicism and even the act of isolating themselves for this sexual deviation is the main reason the act masks their gay identity, before knowing that his true identity is gay, they get lots of friends, so intimate and have a good relationship. Unlike when some of the communities know their true identity as gay, they suddenly lose some of their nearest people and feel like they are isolated from their social community. Because of this gay group, according to informants prefer to cover the original identity in order to avoid such treatment from the daily environment. But according to research informants, each gay individual has their own way to be able to cover his identity.

As is done by all informants of this research, which hide their true identity as a gay is by doing things that they should do in real life (offline). They act as normal men, have female lovers and behave like men generally. If $\mathrm{SN}$ and TN are masculine-looking male figures, then in their daily life there is no need to appear artificial. Both just need to be careful when dealing with her lover online and offline. In contrast to $\mathrm{DD}, \mathrm{AB}$ and $\mathrm{AN}$, is a feminine male figure, therefore they often do a lot of acting in everyday life (offline). This is done to hide his gay identity. For example, when they are close to their strength, or together with their friends, they will pretend to be more masculine. Even they are very close to the private area like a private room that is not allowed all his friends to see and enter into it. This is because in the private room there are items such as dolls, flowers, and other feminis accessories which is their original identity.

The existence of social media Instagram then informants just a little develop what has been described in Instagram. In addition, this media also helps clarify what can not be explained directly in the real world. An example of a DD informant, in Instagram it is depicted that there is a female figure as her lover. DD displays a profile photo, photos togetherness in the real world (offline) with his girlfriend who is clearly visible on Instagram. DD wants to communicate to the public that he is a normal male figure who already has a lover, although the female figure in the media is a delusion. While the frontstage in the real world is action or continuation after what is done in Instagram to 
cover its identity as gay. The informant just needs to affirm to his or her life environment what is on Instagram is the same as in real life. Backstage is the most private space owned by the informant when alone or with his partner where nothing is hidden in his interaction.

\section{Discussion}

In everyday life, everyone will interact with other people with various backgrounds and for certain interests. In interacting, identity becomes something important that is always attached to a person. Identity can come from family, gender, culture, ethnicity and the socialization process. Or in other words, identity is a reflection of ourselves and other people's perceptions of us. To obtain an identity, a person is willing to do several ways in an effort to show identity. One way this is done is through social media. In Indonesia there has been a lot of research: Path (Prakoso, 2017); Blog (Nurhaini, 2017); Instagram (Mahendra, 2017) and Facebook (Khazraee \& Novak, 2018). In China, stigmatization and discrimination against gays and lesbians is almost non-existent. Even the research conducted by (Zheng et al., 2022) on A natural language processing and machine learning approach, describes that Weibo as a search engine in China expresses the feelings and emotions of gay and lesbian people through emoticons. This research reveals how gay groups construct self-identity through social media Instagram. Instagram is used as a medium to shape, change or even eliminate self-identity as 'gay'. This group communicates itself by displaying photos, videos, comments and things they have. The issue of identity becomes something that is dynamic and can be formed. In social media, this is very possible because everyone can design whatever they want and are not displayed through their account. The five informants in this study did the same thing with their identity through social media Instagram. In relation to their status as part of a gay group, informants tried to design their own identity through posting photos, videos and comments through their respective accounts. This informant's self-appearance gives an impression to the public (followers and friends of the informant) regarding his identity. Informants are a group of teenagers who are very active in using social media. Social media has many positive and negative impacts on teenagers: informal learning and teaching experiences (Fox \& Ralston, 2016); youth mental health (Nesi, 2020); (Yonker et al., 2015); social connection (Clark et al., 2017); and spent time (Riehm et al., 2019).

This phenomenon is carried out because the general public acceptance (in Indonesia) of LGBT groups is still part of deviant behavior that is not appropriate to do. This condition does not only occur in Indonesia. Similar research has been carried out in various countries, including: in the UK by (Chaline, 2015); Estonia by (Tiidenberg \& Allaste, 2018); USA by (Lyons et al., 2020a); Argentina by (Iacub et al., 2019) and China by (Bao, 2020). Some of these studies explain that in various countries LGBT people carry out self-identity construction in various ways to change, cover up or even open themselves in public. The reason of gay groups do this is because of society's acceptance of them, both in everyday life: at work (Ro \& Olson, 2014); (Beer \& Wellman, 2021); (Lyons et al., 2020b), body image (Austen et al., 2020), bulliying (Earnshaw et al., 2016), and even their family.

What is done by gays as stated by Goffman about the front stage and the back stage. The role play played by a person is of course closely related to the goals to be achieved. Gay people play a role in their daily life as normal men for the purpose of recognizing their identity with all their abilities (impression management). Management impression is a building that represents the appearance and maintenance of social identities during interactions. Impression management refers to the image that a person displays during 
interaction. Posting about normal activities in cyberspace is a part that is deliberately carried out by gays with the aim of making the public impress their personal identity as a normal male figure. Virtual worlds can provide a safe place for social movements of marginal and oppressed groups such as LGBT (Mckenna \& Chughtai, 2019). In this case, the virtual media is part of the front stage for performing dramaturgy. But on the other hand, the front stage does not only occur on social media Instagram as a stage or media to construct their identity, the front stage also applies in the real world (offline identity) with Instagram as a media to emphasize that what they do in the real world is true.

The implication of the courage of the informants, namely young gays to show their true identity on social media, one of which has a psychological impact. This is in accordance with research conducted by (Mijas et al., 2021) on Dysregulated by stigma: Cortisol responses to repeated psychosocial stress in gay and heterosexual men. This study illustrates that the impact of stigma and discrimination on gay people can significantly higher cortisol levels. Similar to research by (Toomey et al., 2010) on Gender-Nonconforming Lesbian, Gay, Bisexual, and Transgender Youth explaining that victimization due to perceived or actual LGBT status fully mediates the association between adolescent gender nonconformity and young adult psychosocial adjustment (i.e., life satisfaction and depression). In Indonesia this phenomenon is also felt by young gay people because the higher level of discrimination and stigmatization. Therefore, they feel more psychological and social (psychosocial) pressure either in their immediate environment or in the community. The fact is that many gay people feel comfortable in the virtual world or in a gay community. The existence of gays in Indonesia is not accepted because Indonesian society is thick with the nuances of religiosity (Niko, 2016). Based on the Directorate General of Population \& Civil Registration, Ministry of Home Affairs of the Republic of Indonesia (Direktorat Jenderal Kependudukan dan Pencatatan Sipil Kementerian dalam Negeri Republik Indonesia), June 2021 data shows that the population of Indonesia who are Muslim is $86.88 \%$, which is 236.53 million people.

Other concepts contained in dramaturgy are setting, appearance, manner, and mystification. All informants in this study also carried out this concept in constructing the identity they wanted. They become the main role in the stage they make, in this case Instagram. Instagram is used as the main stage (front stage) with all kinds of settings that have been prepared to support the story and goals to be conveyed to the audience. Settings are profiles that are displayed on Instagram. The purpose of this setting is necessary to provide a sense of security, especially for psychological (Matsick et al., 2020). Appearance is an activity to update status and upload photos on Instagram. Manner is the role that informants expect when carrying out activities on Instagram and mystification is the way that informants provide distance to friendship on Instagram. Some of these concepts support the success or failure of impression management carried out by informants, namely how to get a good impression on Instagram without other people knowing that there are other things that are hidden by Instagram users because they are considered to damage impression management itself. Gay groups seem to depend on social media because they are considered able to provide space for freedom of expression. Social media is increasingly popular among LGBT (Han et al., 2019) and 'coming out' by LGBT (Crowson \& Goulding, 2013).

\section{Conclusion}

Construction of gay identity through Instagram media is done by hidden gay and open gay by having the same goal that is to cover the real condition in the real life (offline 
identity). Discriminatory and rejection of family and environment become the dominant factor of the emergence of constructive identity behavior in Instagram media. The construction of gay identity is done in different ways, including by adding some of what is in it, and some by removing all of their original identities. The construction of this identity is used to assert that what happens in the offline world is a fact. For the further research can be focused on the implication on self disclousure gay community on their social media.

\section{Conflict of Interest}

We certify that there is no conflict of interest with any financial, personal, or other relationships with other people or organization related to the material discussed in the manuscript.

\section{Acknowledgements}

The authors would like thanks to Our Rector for giving us permission and funding to finishing process our research. And we would to thanks to our informants who have been willing to spend time during research and giving their life experience.

\section{References}

Alarie, M., \& Gaudet, S. (2013). “I Don 't Know If She Is Bisexual or If She Just Wants to Get Attention ": Analyzing the Various Mechanisms Through Which Emerging Adults. 13, 191-214. https://doi.org/10.1080/15299716.2013.780004

Austen, E., Greenaway, K. H., \& Griffiths, S. (2020). Differences in weight stigma between gay, bisexual, and heterosexual men. Body Image, 35, 30-40. https://doi.org/10.1016/j.bodyim.2020.08.002

Azhari, N. K., Susanti, H., \& Wardani, I. Y. (2019). The voice of Indonesian gay men who want to have heterosexual orientation. Enfermeria Clinica, 29, 500-504. https://doi.org/10.1016/j.enfcli.2019.04.075

Balsam, K. F., \& Mohr, J. J. (2007). Adaptation to Sexual Orientation Stigma: A Comparison of Bisexual and Lesbian / Gay Adults. 54(3), 306-319. https://doi.org/10.1037/0022-0167.54.3.306

Bao, H. (2020). Book Review. Sexualities, O(0), 1-3. https://doi.org/10.1177/1363460720902726

Beer, F. M., \& Wellman, J. D. (2021). Implication of stigmatization on investors financial risk tolerance: The case of gay men. Journal of Behavioral and Experimental Finance, 31, 100513. https://doi.org/10.1016/j.jbef.2021.100513

Berger, P. L., \& Luckmann, T. (2011). The Social Construction Of Reality. Penguin Book. Chaline, E. (2015). The Construction, Maintenance, and Evolution of Gay SM Sexualities and Sexual Identities : A Preliminary Description of Gay SM Sexual Identity Practices. $\quad$ Sexualities, 13(3), 338-356. https://doi.org/https://doi.org/10.1177/1363460709363323

Clark, J. L., Algoe, S. B., \& Green, M. C. (2017). Social Network Sites and Well-Being : The Role of Social Connection. Psychological Science, 1-6. https://doi.org/10.1177/0963721417730833

Crowson, M., \& Goulding, A. (2013). Virtually homosexual: Technoromanticism, demarginalisation and identity formation among homosexual males. Computers in Human Behavior, 29(5), A31-A39. https://doi.org/10.1016/j.chb.2013.01.017

Diniati, A. (2018). Konstruksi Sosial Melalui Komunikasi Intrapribadi Mahasiswa Gay 
di Kota Bandung. Jurnal Kajian Komunikasi, 6(2), 147. https://doi.org/https://doi.org/10.24198/jkk.v6i2.13768

Earnshaw, V. A., Bogart, L. M., Poteat, V. P., Reisner, S. L., \& Schuster, M. A. (2016). Bullying Among Lesbian, Gay, Bisexual, and Transgender Youth. Pediatric Clinics of North America, 63(6), 999-1010. https://doi.org/10.1016/j.pcl.2016.07.004

Fox, J., \& Ralston, R. (2016). Queer identity online: Informal learning and teaching experiences of LGBTQ individuals on social media. Computers in Human Behavior, xxx, 1-8. https://doi.org/10.1016/j.chb.2016.06.009

Han, X., Han, W., Qu, J., Li, B., \& Zhu, Q. (2019). What happens online stays online? - Social media dependency, online support behavior and offline effects for LGBT. Computers in Human Behavior, 93(September 2018), 91-98. https://doi.org/10.1016/j.chb.2018.12.011

Iacub, R., Arias, C. J., \& Mansinho, M. (2019). Sociocultural Changes and the Construction of Identity in Lesbian and Gay Elderly People in Argentina. The International Journal of Aging and Human Development, O(0), 1-17. https://doi.org/10.1177/0091415019836928

Jaspal, R. (2015). Non-Heterosexual British Asian Men : Social Representations , Identity and Social Relations. In International Encyclopedia of Social \& Behavioral Sciences (Second Edi, Vol. 16). Elsevier. https://doi.org/10.1016/B978-0-08097086-8.10221-1

Jordan, T. (2000). Cyberpower: The Culture and Politics of Cyberspace and the Internet. 6 No.2, 248. https://doi.org/https://doi.org/10.1177/135485650000600210

Kasperiuniene, J. (2019). A Systematic Literature Review on Professional Identity Construction in Social Media. SAGE Open, January-May, 1-11. https://doi.org/10.1177/2158244019828847

Khazraee, E., \& Novak, A. N. (2018). Digitally Mediated Protest: Social Media Affordances for Collective Identity Construction. Social Media + Society, JanuaryMa, 1 -14. https://doi.org/10.1177/2056305118765740

Lailiyah, N. (2015). Presentasi Diri Netizen dalam Konstruksi Identitas di Media Sosial dan Kehidupan Nyata Nuriyatul. Ilmu Sosial, 14(2), 20-27.

Lyons, B. J., Lynch, J. W., \& Johnson, D. (2020a). Organizational Behavior and Human Decision Processes Gay and lesbian disclosure and heterosexual identity threat: The role of heterosexual identity commitment in shaping de-stigmatization. Organizational Behavior and Human Decision Processes, 160(March), 1-18. https://doi.org/10.1016/j.obhdp.2020.03.001

Lyons, B. J., Lynch, J. W., \& Johnson, T. D. (2020b). Gay and lesbian disclosure and heterosexual identity threat: The role of heterosexual identity commitment in shaping de-stigmatization. Organizational Behavior and Human Decision Processes, 160(February 2019), 1-18. https://doi.org/10.1016/j.obhdp.2020.03.001

Mahendra, B. (2017). Eksistensi Sosial Remaja dalam Instgram. Visi Komunikasi, 16(01), 151-160.

Mallory, C., Brown, T. N. T., Russell, S., \& Sears, B. (2017). The Impact of Stigma and Discrimination Against LGBT People in Texas (Issue April). Ucla School of Law. https://doi.org/https://doi.org/10.1037/0022-0167.54.3.306

Matsick, J. L., Kim, L. M., \& Kruk, M. (2020). Facebook LGBTQ Pictivism : The Effects of Women' s Rainbow Profile Filters on Sexual Prejudice and Online Belonging. Psychology of Women Quarterly, 1-20. https://doi.org/10.1177/0361684320930566 
Mcclelland, S. I., \& Rubin, J. D. (2016). Adapting to Injustice : Young Bisexual Women's Interpretations of Microaggressions. Psychology of Women Quarterly, 1-19. https://doi.org/10.1177/0361684316664514

Mckenna, B., \& Chughtai, H. (2019). Resistance and Sexuality in Virtual Worlds: An LGBT Perspective. Computers in Human Behavior, 5632 (19). https://doi.org/10.1016/j.chb.2019.106199

Mijas, M., Blukacz, M., Koziara, K., Kasparek, K., Pliczko, M. P., Galbarczyk, A., \& Jasienska, G. (2021). Dysregulated by stigma: Cortisol responses to repeated psychosocial stress in gay and heterosexual men. Psychoneuroendocrinology, 131(May), 105325. https://doi.org/10.1016/j.psyneuen.2021.105325

Moleong, L. J. (2017). Metodologi Penelitian Kualitatif (Revisi). Remaja Rosdakarya.

Napoleoncat.com. (2020). Instagram users in Indonesia. https://napoleoncat.com/stats/instagram-users-in-indonesia/2020/04/

Nesi, J. (2020). The Impact of Social Media on Youth Mental Health : Challenges and Opportunities. NCMJ, 81(2), 116-121.

Niko, N. (2016). Membedah "Normalisme" dan Stigmatisasi Gay Dalam Pemberitaan Media Di Indonesia. Communicate, 1(2), 105-114.

Nurhaini, E. R. (2017). Konstruksi Identitas Diri Blogger Pada Blog Tentang Kepustakawanan. ADLN.

Owens, Z. D. (2016). Is it Facebok Official? Coming out and Passing Strategies of Young Adult Gay Men on Social Media. Journal of Homosexuality, 8369(June), 431-449. https://doi.org/10.1080/00918369.2016.1194112

Prakoso, S. (2017). Coming Out Gay Dalam Media Sosial Path. Universitas Muhammadiyah Surakarta.

Rahmawan, A. D., \& Sujadmi, S. (2021). Dinamika Identitas Gay Di Ruang Publik Toboali Bangka Selatan. Jurnal Analisa Sosiologi, 10(1). https://doi.org/10.20961/jas.v10i1.47615

Riehm, K. E., Feder, K. A., Tormohlen, K. N., Crum, R. M., Young, A. S., Green, K. M., Pacek, L. R., Flair, L. N. La, \& Mojtabai, R. (2019). Associations Between Time Spent Using Social Media and Internalizing and Externalizing Problems Among US Youth. JAMAPsychiatry, 21205, 1-8. https://doi.org/10.1001/jamapsychiatry.2019.2325

Ro, H., \& Olson, E. D. (2014). The effects of social justice and stigma-consciousness on gay customers' service recovery evaluation. Journal of Business Research, 67(6), 1162-1169. https://doi.org/10.1016/j.jbusres.2013.05.006

Spies, L. A., \& Gayla, S. (2014). Growing Up Wired: Social Networking Sites and Adolescent Psychosocial Development. Clin Child Fam Psychol Rev, 17, 1-18. https://doi.org/10.1007/s10567-013-0135-1

Tiidenberg, K., \& Allaste, A.-A. (2018). LGBT activism in Estonia: Identities , enactment and perceptions of LGBT people. Sexualities, O(0), 1-18. https://doi.org/10.1177/1363460718797262

Toomey, R. B., Ryan, C., Diaz, R. M., Card, N. A., \& Russell, S. T. (2010). Gendernonconforming lesbian, gay, bisexual, and transgender youth: School victimization and young adult psychosocial adjustment. Developmental Psychology, 46(6), 1580-1589. https://doi.org/10.1037/a0020705

Triputra, P., \& Rewindinar. (2020). Pseudonym And Persona Management In Psychoanalisys Approach Among J-Pop Fans In Social. Bricolage, 6(1), 35-49.

Yonker, L. M., Zan, S., Scirica, C. V, Jethwani, K., \& Bernard, T. (2015). “Friending ” 
Teens : Systematic Review of Social Media in Adolescent and Young Adult Health Care Corresponding Author: JMIR, 17, 1-15. https://doi.org/10.2196/jmir.3692

Zheng, Q., Guo, Y., Wang, Z., Andrasik, F., Kuang, Z., Li, J., Xu, S., \& Hu, X. (2022). Exploring Weibo users' attitudes toward lesbians and gays in Mainland China: A natural language processing and machine learning approach. Computers in Human $\begin{array}{lll}\text { Behavior, } & \text { 127(September } & 2021),\end{array}$ https://doi.org/10.1016/j.chb.2021.107021 